S. Ewa Korbut, MSF

Cardinal Stefan Wyszynski University

\title{
The Holy Family as a Model of the Spiritual Life in Bl. Bolesława Lament's Teaching
}

The Christian spiritual life, the essence of which is holiness, needs an example that sheds clear light on the path of love for God and neighbor. In her teachings, BI. Bolesława Lament indicates that the example of the Holy Family of Nazareth's life is especially helpful in for man's spiritual development. The Holy Family's example can help shape the spiritual life of believers according to the Incarnation. The essence of the Holy Family's example is its deep focus on the mystery of Incarnation and, thus, union with Christ, the Incarnate Word. Moreover, the hidden life of Jesus, Mary, and Joseph provides a solid foundation on which apostolic life can take on form.

Key words: BI. Bolesława Lament, Holy Family, spiritual life, spirituality of Nazareth, incarnational concept of the spiritual life.

\section{Introduction}

While the theological literature does not often discuss the subject of the Holy Family of Nazareth, this does not mean that the role of Holy Family should be marginalized or treated simply. Joseph Ratzinger himself warned against such underestimation years ago, writing as follows: "Nazareth has an abiding message for the Church [...] The universal Church can grow and flourish only if she is aware that her hidden roots are kept safe in the atmosphere of Nazareth. [...] The Church can always begin anew from that place and recover her health from that place [...] If the Church is to make the correct response to our 
Theology of Spirituality

century's cries of protest [...] Nazareth must remain an experiential reality in her own self." ${ }^{1}$

Bl. Bolesława Maria Lament, ${ }^{2}$ who is well known in in the Roman Catholic Archdiocese of Białystok, grew in holiness by modeling her spiritual life on the life of Jesus, Mary, and Joseph in Nazareth. She also encouraged the members of the Congregation that she founded-the Missionary Sisters of the Holy Family - to do the same. Bl. Bolesława Lament's writings contain interesting reflections on the Holy Family that are both useful and applicable to the life of every believer.

\section{The credibility of the model}

Drawing upon the Bl. Bolesława Lament's legacy, it is clear that the Family of Nazareth provides an exceptional and unique example of the spiritual life because Jesus, Mary, and Joseph are the most holy people to have ever lived and their life in Nazareth serves as a reflection of the Holy Trinity. Mother Bolesława understood that her main task was to make the Holy Family a living reality within her life and thereby extend the spirit of Nazareth into the current day. ${ }^{3}$

1 J. Ratzinger, The God of Jesus Christ, San Francisco 2008. (Abbreviated hereafter as The God)

2 Bolesława Maria Lament was born on July 3, 1862 in Łowicz. At the age of 22, she joined the Congregation of the Sisters of the Family of Mary. However, because of her uncertainty regarding her vocation, she returned to her family home in Łowicz before she made her final profession. After her father's death, she moved to Warsaw, where she devoted herself to social work. During her eleven-year stay in Warsaw, her spiritual life deepened under the direction of Father Honorat Koźmiński. At his suggestion, she also went to Mogilev on the Dnieper River (now Belarus) in 1903 to run an educational institution. There, in 1905, she founded the Congregation of Missionary Sisters of the Holy Family, becoming the first superior general of the Congregation, whose goal was to support the work of unifying Christians and strengthening Catholics in their faith. In 1935, she resigned from her duties as Superior General. The new Superior General sent Bl. Bolesława to Białystok. She passed into eternity at 84 years of age on January 29, 1946, in Białystok. Pope John Paul II beatified Bolesława Maria Lament on June 5, 1991 in Białystok during his fourth pilgrimage to Poland.

Cf. B. Lament, Directory of the Congregation of the Missionary Sisters of the Holy Family, vol. 3, Białystok 1944, 48, 51 (abbreviated hereafter as DBL3); "Do we appreciate the grace that Providence deigned to give us as guardians to guard giving us as guardians these three most holy beings that the earth has never had and will never have." B. Lament, Directory of the Congregation of the Missionary Sisters of the Holy Family, vol. 1, Białystok 1944, (abbreviated hereafter as DBL1); Cf. J. Ratzinger, The God, 79; E. Korbut, The spirituality of the Missionary Sisters of the Holy Family, Warszawa 2018, 365. 
The starting point of the spiritual life is to have a proper knowledge of God because this enables an individual to maintain a proper trajectory of development. ${ }^{4}$ By emphasizing the need to know God in one's spiritual life, Bl. Bolesława perceived that the life of the Holy Family provides valuable knowledge about Jesus Christ. Pope Paul VI states something similar: "Nazareth is the school where one begins to understand Jesus: it is the school of the Gospel. Here, above all, we learn to look, listen, ponder and penetrate the profound and mysterious meaning of this very simple, humble and beautiful revelation of the Son of God [...] Here, we are given the opportunity to fully understand who Christ is." ${ }^{5}$ According to Bl. Bolesława Lament, the mysteries of the life of the Holy Family enable the faithful to know Jesus in his divinity and humanity with all clarity and without deviation. Above all, the Holy Family makes it possible to know God, who is close to man, as both Savior and Brother. ${ }^{6}$ Their life provides a context to know Jesus who, although God, became man to come closer to men, offers His friendship, "seek[s] and save[s] what was lost" (Lk 19:10), desires not the "death of the wicked, but that the wicked turn from his way and live" (Ez 33:11), and Who is patiently waiting for man to accept His forgiveness. ${ }^{7}$

Coming to know Jesus of Nazareth is the starting point for coming to know oneself as well, without pride or discouragement, because knowledge of Christ reveals the "infinite horizon of His mercy." 8 The fruit of this knowledge is a proper relationship with Jesus that is based on trust and is one in which fear, terror, and intimidation disappear. A trusting attitude consoles the heart and deepens hope and love, which

$4 \quad$ Cf. DBL3, 36, 40; Cf. J. Bochenek, Zarys ascetyki, Warszawa 1972, 337; R. Garrigou-Lagrange, Trzy okresy życia wewnętrznego, vol. 1, trans. S. Teresa Franciszkanka Służebnica Krzyża, Poznań 1960, 271-272; J. W. Gogola, Teologia komunii z Bogiem, Kraków 2003, 111.

5 Paweł VI, "Przemówienie Ojca Świętego z okazji Nawiedzenia Bazyliki Zwiastowania w Nazarecie, 05 I 1964,” in: Liturgia Godzin, vol. 1, 378-379.

$6 \quad$ Cf. DBL3, 359-360, 364, 366.

7 Cf. ibid., 359-360.

$8 \quad$ Ibid., 364. 
Theology of Spirituality

has the power to transform ${ }^{9}$ and makes it possible to rise to God to praise His inexhaustible goodness. ${ }^{10}$

\section{An incarnational understanding of the spiritual life}

By choosing the Holy Family as a model in her spiritual life, Mother Bolesława Lament adopted an incarnational understanding of spiritual life. The life of the Holy Family is the life of the Incarnate Word, where Mary and Joseph become the first disciples to be closely united with Jesus in the simple life of Nazareth. ${ }^{11}$ Jesus, Mary, and Joseph remained united in mind and in all powers of spirit. Mary "faithfully persevered in her union with her Son unto the cross" (LG 58), and was united with her Bridegroom, Joseph, through the bond of marriage. Through his marriage to the Blessed Virgin, and through his care for her and the Son, St. Joseph was united in a special way with the faith of Mary and the Heart of the Son of God. In this sense, the Holy Family belong to the Order of Hypostatic Union and is part of the Divine logic of the Incarnation. For this reason, as Benedict XV pointed out, we can go from St. Joseph to Mary and through Her to Jesus (cf. Bonum

$9 \quad$ Cf. ibid.; Cf. R. Rybicki, "Wychowawca Jezusa Chrystusa," in: Józef z Nazaretu, ed. O. Stokłosa, vol. 2, Kraków 1979, 305-306; R. Rybicki writes that the Incarnation is not only a soteriological doctrine, but also a model for life based on Mary and Joseph's life and their mission in relation to Jesus make on reevaluate what is earthly and horizontal by making it harmonize with what is eternal, divine, and universal. This mystery shows that not only Mary and Joseph but also every believer can grow in a relationship with the Messiah.

Cf. DBL3, 75; "Be glorified, sweet Jesus, for Your words and Your examples that teach me life! I understand now what I should do for You and what You have done for me! You became the embodiment of humility, you were born into poverty, you lived a life of suffering. You have placed the depth of human pain on the hills of his passing glory. You walked before me despised and suffering, calling me to follow you along the same path, without leaving it until I die." Ibid.

Cf. ibid., 52; An incarnational understanding of the spiritual life is not a philosophical approach that upholds a positive approach to the world because it upholds that God created the world that the Son of God subsequently accepted. Rather, an incarnational understanding entails a radical union with Christ, the Incarnate Word (Verbum Incarnatum). This approach introduces man to the world of God's mysteries that take place within the mystery of the Incarnation and leads a person to be cleansed radically of imperfection. it also leads man into God's nature - that is, it deifies man, and ushers him into the life of the Trinity. Cf. S. Nowak, "Mistyka inkarnacyjna Wcielonego Słowa," in: Mistyka droga zjednoczenia z Bogiem, eds. S. Urbański, M. Szymula, Warszawa 1999, 35, 42; E. Korbut, The Spirituality, 362-363. 
sane). ${ }^{12}$ This spiritual path does not stop at the person of Jesus; for, He always leads to the Father and the Holy Spirit, thus bringing man into the life of the Trinity. ${ }^{13}$

Bl. Bolesława Lament focused particularly on the spirit of deep union with God that existed within the Holy Family. The mundane nature of their life in Nazareth and their depth of their union with God is not something reserved just for higher stages of spiritual life; instead, it is universally attainable and does not require special external conditions. ${ }^{14}$ Theologians have asserted that understanding the mystery of the Incarnation is the basis for union with God..$^{15}$ According to Bolesława Lament, the spirit of union with God that prevailed in the Holy Family of Nazareth it primarily Christocentric. Everything within the Holy Family found its origin in Jesus and was directed to Him. Because of Jesus' presence among them, Mary and Joseph continued to grow in ardent love. Jesus first filled His Mother's heart with grace, and She, in turn, imparted these graces to St Joseph. Mary and Joseph's union with Jesus fostered a spiritual communion between Mary and Joseph within the context of the reality of their daily duties. The most important thing, however, was Mary and Joseph's love for Jesus, which motivated them strive to know Him more and more deeply and to follow Him more closely. Bl. Bolesława Lament understood the essence of this knowledge as probing Jesus' feelings, thoughts, and all of His movements (even the slightest) to the point of becoming a faithful reflection of Him. And since Mary and St. Joseph are faithful reflections of Jesus, Bl. Bolesława advised people not only to study and understand deeply the life of Jesus Himself, but also to examine the lives of Joseph and Mary, since their example is helpful

12 Cf. F. Schreder, "Św. Józef a zjednoczenie hipostatyczne," in: L. Strada, Patron doskonaty, Kraków 1976, 30; S. Nowak, "Mistyka inkarnacyjna," 38.

13 Cf. C. A. Bernard, Wprowadzenie do teologii duchowości, trans. J. Machniak, Kraków 1996, 127.

$14 \quad$ Cf. P. Ogórek, "Mistyka. Zagrożenie czy rozwój życia duchowego?,” in: Mistyka droga zjednoczenia z Bogiem, eds. S. Urbański, M. Szymula, Warszawa 1999 17, 19-29; "Living in union with God is not about receiving extraordinary gifts from God, but about developing love." Cf. S. Urbański, "Początek duchowości inkarnacyjnej - 'Gdy nastała pełnia czasu' (Ga 4:4),” in: Gdy nastała petnia czasu, ed. A. J. Nowak, Lublin 2001, 204.

15 Cf. ibid.; S. Nowak, "Mistyka inkarnacyjna," 35; "Wcielenie Syna Bożego jako podstawa duchowości chrześcijańskiej,” in: Gdy nastała petnia czasu, ed. A. J. Nowak, Lublin 2001, 146. 
Theology of Spirituality in growing in a deeper union with Jesus, ${ }^{16}$ which also entails union with the Trinity. ${ }^{17}$

The mystery of the Holy Family's life reveals the value of ordinary daily reality within the spiritual life. Like G. Greshake, Bolesława Lament emphasized that everyday life is tailored completely to what is ordinary, mundane, and monotonous. This seemingly bland and inconspicuous everyday life in Nazareth even takes away something of the extraordinariness of kenosis and thereby opens man up to a different, higher reality. ${ }^{18} \mathrm{Bl}$. Bolesława perceived how the Holy Family's everyday life made them closer to and more like us. Jesus' natural closeness to Mary and Joseph pushes us to follow their example. Their life is a practical, concrete, and accessible model ${ }^{19} \mathrm{Bl}$. Bolesława also indicated that the basic message of the Holy Family's everyday life in Nazareth is to grow in wisdom and grace with God and man (cf. Lk 2:52). ${ }^{20}$ They carried out this task by doing the most common activities. Therefore, the spiritual life is not about doing great or admired things, but rather about putting a quiet and simple love into everything. ${ }^{21}$ Such spiritual growth focuses on fulfilling one's daily duties well and becomes effective on the path of ardent love. ${ }^{22}$ Love gives value to our actions, and love removes the apparent blandness and monotony from Christian

16 Cf. B. Lament, Directory of the Congregation of the Missionary Sisters of the Holy Family, vol. 2, Białystok 1944, 288 (abbreviated hereafter as DBL2); DBL3, 51-52, 333; A. Doze emphasizes that Mary and Joseph are an integral part of the mystery of Christ. In his teaching, St. Irenaeus, states that just as God the Father works with two hands (i.e., the Son and the Holy Spirit), so to does the Son (i.e., the Mother of God and the Guardian of Jesus and the Virgin). Cf. A. Doze, Józef, cień Ojca. Refleksje z duchowości nazaretańskiej, trans. L. Balter, Kalisz 2006, 203.

17 "The sisters will look at Jesus and ponder His deeds, because this is the easiest way to get to know God, because whoever sees Jesus sees the Father, because He and the Father are one." See DBL3, 152.

18 Cf. DBL2, 196; DBL3, 48-49; Cf. G. Greshake, "Duchowość Nazaretu," trans. L. Balter, Communio 1(2005): 110-111. The author points out that the fact that the Son of God lived a monotonous life in Nazareth for thirty years is the deepest mystery of Nazareth. He also points out how this mystery is connected in a particular way with and reinforces Phil 2:6, which speaks about the self-emptying of the Son of God.

19 Cf. DBL3, 48-49.

20 Cf. ibid., 36, 40.

21 Cf. ibid., 329; Cf. A. Doze, Józef, cień Ojca, 180.

22 Cf. DBL3, 40-41, 329. 
life. Love opens man up to a new and completely supernatural and fruitful life and gives him a taste of happiness here on earth. ${ }^{23}$

When considering the mystery of the Holy Family's life, Bl.

Bolesława saw that they appreciated their everyday life, in which the lowliest activities were divinized through fervent charity. ${ }^{24}$ She claimed that recalling the Holy Family's everyday life in Nazareth and their great holiness, the faithful grow in noble courage to continually surrender to the duties imposed on them by their daily Christian lives. Truly pious hearts that burn with a love that is stronger than death are formed on this path. This way to holiness does not focus on methods or constantly changing plans ${ }^{25}$ but on a simple and consistent effort to unite one's life and will with the Incarnate Word and, through Him, with the whole Trinity. Referring to S. Nowak, this path to holiness involves "a true transfusion of [Jesus'] being and His spiritual action in us, and especially a transfusion of His prayer, feelings, and adoration of God the Father. In this way, Jesus becomes not only our example but also our life and our "everything." ${ }^{26}$ Bolesława Lament thought that the Incarnate Word and His Parents' life together should not only be meditated upon and imitated, but also that it serves as a reminder that the present moment and reality are always a source of grace. The mystery of the Incarnation, therefore, is the basis of our sanctification and of our divinization through the life of the Son of God on earth. S. Nowak considers this insight a crucial because it enables one to understand and grasp the meaning of incarnational mysticism. ${ }^{27}$

According to Mother Bolesława Lament, through its deep bond with the Mystery of the Incarnate Word, the hidden life of the Holy Family serves as a solid foundation for asceticism. This life is one of unceasing and continual mortification..$^{28}$ Above all, Bolesława Lament

$23 \quad$ Cf. ibid., 329-330.

$24 \quad$ Cf. ibid., 329.

25 Cf. ibid., 48, 51, 333; Today, everyday life is considered something negative. Contemporary man seeks to find meaning in his life by experiencing an abundance of extraordinary things. The message of the Holy Family's daily life in Nazareth runs counter to this. In light of the Holy Family's life, everyday life is not, as G. Greshake asserts, a meaningless settling down, but rather an a gift from God, due to which a person can discover the fullness of meaning, which is to grow in love. When a person accepts this monotonous reality, then vistas that open him to perceiving the sanctifying value of ordinary life open up before him. Cf.

G. Greshake, "Duchowość Nazaretu," 111.

S. Nowak, "Mistyka inkarnacyjna," 38. 
Theology of Spirituality

showed that everyday life is the main context in which an individual can practice asceticism (i.e., mortification) and focus on developing the proper dispositions when faced with daily adversities and humiliation. She stressed the need to persevere and remain faithful in spiritual life despite the difficulties that a person encounters. Mother Bolesława asserted that the asceticism that flows from the hidden life is the most effective because it humiliates human pride. ${ }^{29}$ When practiced well, this asceticism becomes, on the one hand, a lesson in patience that protects individuals from bitterness, and, on the other hand, a lesson in optimism because the Holy Family's example and an awareness that They won for us the grace to endure strengthens the individual. Bl. Bolesława recommends, therefore, that missionaries should practice asceticism in communion with Jesus hidden in Nazareth..$^{30}$

A spirit of silence that permeated the Holy family's daily life is the main feature that corresponds to the spiritual life. ${ }^{31}$ As Paul the VI conveys, the Holy Family teaches the faithful respect for silence. ${ }^{32}$ According to Bl. Bolesława, silence is closely connected with and naturally integral to the hidden life of the Holy Family. ${ }^{33}$ When describing the spirit of silence, she uses such expressions as: solitude of heart, silence, and quiet, and she makes the distinction between external and internal silence. According to Bl. Bolesława's teaching, the Holy Family's spirit of silence is not limited to simply refraining from speaking. Maintaining an atmosphere of external quiet makes it easier to maintain interior silence, but this aspect does not exhaust the meaning of silence. Exterior quietude is meant to foster proper silence. ${ }^{34}$ The essence of the silence observed in Nazareth is a state of deep concentration, by which the members of the Holy Family constantly lifted their souls to

29

30

31

See DBL3, 77-78.

Cf. DBL3, 40, 77-79.

Pope Pius XII, Paul VI, and John Paul II's teachings as well as different theological studies state that the spirit of silence was characteristic within the house of Nazareth. Cf. Pius XII, "Modlitwa do św. Józefa Robotnika," in: F. L. Filas, Święty Józef człowiek Jezusowi najbliższy, trans. F. Dylewski, J. Ożóg, D. Siuta, Kraków 1979, 438; Paweł VI, "Przemówienie Ojca Świętego," 168; RC 25; Cf. J. Galot, "Święty Józef," in: Józef z Nazaretu, ed. O. Stokłosa, vol. 1, Kraków 1979, 267-270; T. Paszkowska, "Wierny prawu i Duchowi - Święty Józef wzorem dla konsekrowanych," in: Duchowość św. Józefa, ed. M. Chmielewski, Lublin 2003, 122-123.

Paweł VI, “Przemówienie Ojca Świętego,” 168.

Cf. DBL3, 74, 76; "Through a hidden life we come to understand a life lived in solitude of heart, a life that follows the example of Jesus' life in Nazareth."

Cf. DBL2, 217-218. 
God and united themselves with God even during conversation, work, or rest. ${ }^{35}$ In this way, a spirit of silence means remaining in union with and continual adoration of God. It is the focus by which Mary and St. Joseph preserved all of Jesus' words and deeds, meditated on them in their hearts, and applied them to their daily lives. The faithful should seek this silence, so that they can recreate in their own lives the same spirit of silence that permeated the life of the Holy Family. ${ }^{36}$

Mother Bolesława Lament also highlighted that the Holy Family models the many virtues that they developed gradually, over time. ${ }^{37}$ Among the Holy Family of Nazareth's virtues that she encouraged the missionaries of her order to grow in are: faith, obedience, poverty, humility, simplicity, meekness, modesty, concentration, the perfection of good works, ${ }^{38}$ and sacrificial love, ${ }^{39}$ which was the most characteristic and supreme virtue in the life of the Holy Family. Bl. Bolesława Lament taught that every activity and action that the Holy Family of Nazareth carried out was permeated with charity. ${ }^{40}$ They directed this love firstly to God and His will and then to man. ${ }^{41}$ Their charity shaped the other virtues by giving them a supernatural motive..$^{42}$ This is the reason why Mother Bolesława Lament stated that everything is great if one's love is great..$^{43}$ In this way she demonstrated the relationship between charity and the other virtues. For the virtue of charity forms an organic whole of all practiced virtues. An increase of one virtue will always entail an increase in the other virtues. ${ }^{44}$ In the life of the faithful, this means focusing on developing various virtues, but above all deepening love, which "is the bond of perfection" (Col 3:14).

$35 \quad$ Cf. DBL3, 40.

$36 \quad$ Cf. DBL2, 218; "May peace, quiet, silence, mutual charity, and union with Jesus our Heavenly Spouse flourish in our convents. Every home or convent must a little home in Nazareth, and its inhabitants must imitate Jesus, Mary, and Joseph in order to be worthily called Missionaries of the Holy Family."

37 "Look at the details of His simple and common life ... study all the virtues that developed with age." DBL3, 40; Bl. Bolesława Lament emphasized that Jesus, as the Son of God, could not grow in virtue within his soul. In his case, he grew in virtue in the daily activities that marked His holiness outwardly.

38 See ibid., 2-3, 37-38, 40, 42-45, 329, 333.

39 Cf. DBL2, 218, 288; DBL3, 40.

$40 \quad$ Cf. DBL2, 176.

41 Cf. DBL3, 40.

$42 \quad$ Cf. DBL2, 176; DBL3, 73, 329.

43 Cf. ibid., 329.

44 Cf. S. Urbański, Teologia życia mistycznego, Warszawa 1999, 89. 
Theology of Spirituality

Charity is the form of the virtues; it expresses them, organizes them, and animates them (cf. CCC 1827). ${ }^{45}$

Bl. Bolesława also considered the Holy Family a model of prayer. The silence fostered enabled a spirit of prayer in Nazareth. She wrote that the most important thing is that the Holy Family of Nazareth prayed without easing, even though their "hands [...] were busy with carpentry work." 46 She observed that everything was a prayer within the Holy Family because their love for the Eternal Father and for human souls was their main motivation for living in Nazareth and because their prayer permeated the Holy Family's work, by which they continuously glorified the Father's will, gave praise, offered thanksgiving, expiated, and made supplication. ${ }^{47} \mathrm{Bl}$. Bolesława wrote that Mary and Joseph's prayer became a contemplative adoration of Jesus through their unceasing meditation on his words and actions. ${ }^{48}$

\section{The Holy Family: a model of dedication to the work of salvation}

God's plan of salvation reached its fullness in the mystery of Christthat is, in the coming of the Son, whom the Father sent to earth to bring God's truth to people and to free them from evil (cf. SC 5; GS 13). Christ began this work in Nazareth "through the help of a virginal union." ${ }^{49}$ Christian life is to be grafted into the mystery of Christ. Thus, a properly established spiritual life must have at its foundations the mystery of Christ and be fully open to it..$^{50}$

Drawing inspiration from the Holy Family of Nazareth's involvement in the work of salvation, Bl. Bolesława Lament believed that

$45 \quad$ Cf. A. Marchetti, Zarys teologii życia duchowego, vol. 1, trans. E. J. Bielecki, Kraków 1996, 56-67.

$46 \quad$ DBL2, 176.

47 Cf. ibid., 176, 218; DBL3, 76-77; Cf. F. L. Filas, Święta Rodzina wzorem dla rodzin, trans. A. Zapał, Sandomierz 2007, 155-163.

Cf. DBL2, 218, DBL3, 52.

49 Paweł VI, "Rodzina szkołą świętości. Przemówienie wygłoszone 4 maja 1970 r.," Ateneum Kaptańskie 84(1975): 6; Joseph Ratzinger points out that Nazareth has an abiding message for the Church. The New Covenant begins in Galilee-a place forgotten by everyone-in the home of the Virgin and a craftsman. Therefore, in order for the Her to carry out Her mission, the Church should find in Nazareth its origin and a vivid reality that make it possible for Her to adequately respond to today's challenges. Cf. J. Ratzinger, Droga Paschalna, trans. W. Szymona, Kraków 2001, 82-83.

Cf. A. Słomkowski, Teologia życia duchowego, Ząbki 2000, 43-44. 
the fruitfulness of this spirituality resulted from participating in the messianic mission of Christ. She believed that those who sought to join the congregation that she founded should be deeply committed Theology of Spirituality to following Christ's example in Nazareth. ${ }^{51}$

When meditating on the life of the Most Holy Family, Mother Bolesława recognized the profound relationship that exists between the mystery of Incarnation and Redemption, ${ }^{52}$ and she emphasized that the mystery of the Incarnation is an integral part of the mystery of the Redemption. She wrote: "The Incarnate Word began the Redemption of the world in Nazareth, in the womb of the Most Holy Family" (cf. CCC 512). ${ }^{53}$ Mother Bolesława pointed out that, although the world was "redeemed primarily by His Cross, ${ }^{54} \mathrm{Christ}$ from the first moment of the Incarnation began the work of Redemption; all his deeds were

51 "In every activity that took place in Nazareth, in every period of his earthly life, the Lord Jesus' Divine Heart was filled with unspeakable love for the Eternal Father and human souls, such that unceasing homage, praise, adoration, worship, love, expiation, supplication and sacrifice flowed from His Heart." DBL2, 176.

Cf. DBL3, 164-165; A theological understanding of the Incarnation includes not only the single act of Christ's Incarnation, but the entire divine-human history of Christ, who was subject to the law of development, duration and growth within a given period of time. The Incarnation, therefore, is therefore treated as a reality that grows and develops throughout the life of Jesus and reaches its climax with his death and resurrection. Cf. W. Hryniewicz, Chrystus nasza Pascha. Zarys chrześcijańskiej teologii paschalnej, vol. 1, Lublin 1982, 278; H. U. von Balthazar, Teologia misterium paschalnego, trans. E. Piotrowski, Kraków 2001, 21; H. Lubac, Paradoksy. Nowe paradoksy, trans. M. RostworskiKsiążek, Kraków 1995, 32-34.

DBL3, 164-165. In the post-apostolic period, two approaches to the theology of redemption developed. The first approach, which is represented by the Eastern Church Fathers (Origen, Clement of Alexandria, Athanasius the Great, Gregory of Nyssa, Cyril of Alexandria), refers primarily to the Incarnation of Christ. The Eastern Church Fathers asserted that mankind was saved through the Son of God's Incarnation, where Christ is the prototype of humanity's reconciliation with God. The second approach, which the Western Fathers (Tertullian, Cyprian, Leo the Great, Gregory the Great) represent, emphasized the Christ's sacrifice. Although the complementarity of the two approaches became recognized over time, the emphasis of one over the other still occurs today. Cf. C. Bartnik, "Odkupienie, usprawiedliwienie i zbawienie," in: Teologiczne rozumienie zbawienia, ed. C. Bartnik, Lublin 1979, 15-16. 
Theology of Spirituality

directed towards this single purpose." ${ }^{55}$ She also emphasized that Jesus constantly recalled his mission during his life in Nazareth. ${ }^{56}$

When emphasizing the connection between the mystery of the Incarnation and the mystery of Redemption, Mother Bolesława also spoke of the salvific dimension of the mystery of hidden life that the Holy Family led in Nazareth. She writes: "Our Master, in order to save the world, was hidden, prayed, and suffered in silence [...] for thirty years." ${ }^{57} \mathrm{Christ}$ 's hidden life was deeply connected with God's eternal plan and was of great value as "the most sure means" 58 of achieving the goal of the Eternal Word, which was to glorify the Father through the restoration and salvation of the human race. The very fact that Christ's hidden life in Nazareth lasted for thirty years, his public ministry lasted for three years, and the passion lasted for three days proves that "the hidden life must therefore have had a great value and a profound meaning, that it must have played a great role in the work of mankind's Redemption." 59 When pointing to the hidden life of the Holy Family as a model of commitment to the work of salvation, Bl. Bolesława also indicated how paradoxical in its seeming insignificance it was, stating that there is nothing extraordinary about the Holy Family's life in Nazareth. ${ }^{60}$

In his own writings, Joseph Ratzinger also reflected on Jesus' hidden life and public ministry. He conveys how Jesus' public life was also marked by hiddenness; for, Jesus experienced loneliness, misunderstanding, and solitude with God. In their accounts, the Evangelists

55

Ibid.

"And what did the Lord Jesus do during this long period of hard and arduous work in his parents' home? There is no doubt that, although it might seem as if he had forgotten the purpose of coming into the world, he had it constantly in mind. He adored, rewarded, prayed, loved, offered Himself ... and, regardless of whether His Divine hands were sawing wood or sweeping the carpentry workshop floor, His Heart always remained in God's presence, and the desires that consumed it rose to the Father in his continual prayer of supplication for his glory and the salvation of the world." DBL3, 76-77; "The spirit of Jesus walking on earth was the spirit of sacrifice. He always had his mission before his eyes and he felt its heavy burden, because he carried the sins of the world upon him, and the fervor that corresponded to this great mission penetrated his heart." DBL1, 299.

Ibid., 282.

DBL3, 76.

DBL2, 176; Cf. DBL3, 76.

"Look at the Immaculate Mother and His Guardian, Saint Joseph. What great deeds did they accomplish during their time in Nazareth? The Scriptures say nothing about this. Indeed, they did not do anything great or extraordinary, anything that would draw attention or arouse the admiration of others." DBL2, 196. 
often mention the fact that Jesus went to quiet and isolated places to pray. Jesus' public ministry was connected closely with hiddenness, which was at its very core: "The public activity of Jesus has its center Theology of Spirituality in this hiddenness, in which it embraces the public dimension of the whole world. It is from this hiddenness that he comes to men and that he with them; and it is in this hiddenness that men gain access to him." 61

Bl. Bolesława Lament's writings reveal that the mystery of the hidden life of the Holy Family of Nazareth is characterized by redemptive sacrifice. She called Jesus' entire life in Nazareth "the strangest desolation," 62 in which He forwent His majesty and annihilated Himself, becoming poor and subservient. ${ }^{63} \mathrm{Bl}$. Bolesława compared the suffering that Jesus experienced in his hidden life to that of the cross. ${ }^{64}$ She also mentioned the poor conditions [of Jesus' birth] in Bethlehem as well as his desecration on the cross. ${ }^{65} \mathrm{Bl}$. Bolesława's analysis allows us to conclude that she understood the Incarnation of the Son of God as kenosis - a real, although hidden, humiliation with a paschal dimension. ${ }^{6}{ }^{6}$

According to Bl. Bolesława Lament, through their profound union with Jesus, Mary and St. Joseph teach us how to participate in the salvific work of Jesus Christ. ${ }^{67}$ This union is based on the theological premise that Mary and, through Her, St. Joseph were the first to be united with Jesus. Mary and St. Joseph participate in the kenosis of living a hidden life and serving, at God's explicit request, the mystery

$61 \quad$ J. Ratzinger, The God of Jesus Christ.

62 DBL2, 73.

$63 \quad$ Cf. ibid. 64-65; DBL3, 73, 42; "The Lord Jesus made an infinitely great sacrifice in deciding to be subject to creatures throughout almost the entire course of his earthly life." Ibid., 45.

$64 \quad$ Cf. ibid., 4, 59, 69, 77; "And behold, from an open heart still pierced in Bethlehem precious tears gush forth." Ibid., 69; Cf. DBL2, 291.

$65 \quad$ Cf. DBL3, 176; "Jesus wants all the poorest, poor in Bethlehem and Calvary, to become his own people." Ibid.; Cf. DBL2, 64-65.

66 Cf. W. Hryniewicz, Chrystus nasza Pascha, 280, 283.

67 Cf. DBL3, 51-52; "Already in the darkness of eternity, before time began to exist, the Immaculate Queen was closely united to the Word in those wonderful plans of Providence which the Savior was to accomplish for the salvation of his sinful children: Co-Redemptrix with the Redeemer, Mother with the Son, universal Mediatrix of all graces with the Grace-Maker." DBL2, 60; F. Schreder notes that Mary and Joseph belong to the Order of the Hypostatic Union because of their special relationship with Christ and the role they played in relation to the Son of God. Cf. F. Schreder, "Św. Józef a zjednoczenie hipostatyczne," 27. 
Theology of Spirituality of the Eternal Word by humbly carrying out their maternal and paternal duties. ${ }^{68}$ Encouraging us to follow Mary and Joseph in their contribution to the work of salvation, Mother Bolesława emphasized their total dedication to God's plan, their submission to God's will, and their obedience of faith-that is, the submission of their reason and will to revealed truth. ${ }^{69}$

Contemporary theology speaks of Mary and St. Joseph's participation in Christ's priestly, royal, and prophetic mission (cf. RC 32). In his analysis, L. Balter points out that Mary's priesthood came about through the Immaculate Conception as the first redemptive grace. Mary participated in Christ's priestly mission because she participated in the origin of Christ's priesthood. In St. Joseph's case, he participated in Christ's priesthood by becoming a pleasing sacrifice to God. Balter emphasizes how priestly and royal missions are united closely. Like Jesus, Mary's royal mission is connected with the priestly sacrifice of her life and the spiritual freedom it brings about. Joseph, on the other hand, fulfills his royal mission by being fully dedicated to the work of salvation to the point of emptying himself and royally serving God for the sake of the mystery of the Incarnation. St. Joseph's prophetic role stems from and is closely associated with his royal priesthood and is an integral part of and a complement to his priestly dignity. This is manifested in the testimony of his life based on faith - a testimony expressed through his silence and work. Mary's prophetic attitude of faith as the virgin who listens to and receives the word makes her the perfect model of what is means to faithfully fulfill God's plan in both spiritual and apostolic life. ${ }^{70}$

In her writings, Bl. Bolesława Lament focused primarily on showing how the Holy Family was fundamentally committed to the work of

$68 \quad$ Cf. DBL3, 3 $, 11,26,28,36,44,48-49,51$; DBL2, 196; “The Blessed Virgin Mary was entrusted with the mission from the Eternal Father to watch over the Baby Jesus and educate him, and she fulfilled her task with all the zeal and inexpressible love that was overflowing from her Immaculate Heart. Until now, on the globe, no mother has loved her child as much as this Divine Mother, and until the end of the world, no mother will have a similar love." Ibid., 288. Cf. DBL3, 10-15, 25-30, 36-38, 41-42, 46-53.

70 Cf. L. Balter, "Problem udziału św. Józefa w kapłańskiej godności Chrystusa," Ateneum Kapłańskie 96(1981): 286-287; "Królewskość św. Józefa," Ateneum Kapłańskie 1(1984): 118-119, 125, 127; “Św. Józef jako Prorok," Ateneum Kapłańskie 3(1985): 462-463, 468-471; Cf. W. Seremak, "Św. Józef - szczególny nauczyciel uczestnictwa w mesjańskiej misji Chrystusa," in: Duchowość św. Józefa z Nazaretu, ed. M. Chmielewski, Lublin 2003, 59-72; H. Wejman, "Józef z Nazaretu wzorem proegzystencji kapłańskiej," in: Duchowość św. Józefa z Nazaretu, ed. M. Chmielewski, Lublin 2003, 85-89. 
salvation. Reflecting on the life of Mary and St. Joseph, she revealed the two conditions necessary to enter properly into Christ's salvific mission: The first condition to be charitable and sensitive to God's Theology of Spirituality will, both of which Mary and St. Joseph perfectly and radically exemplify. ${ }^{71}$ The second necessary condition is contemplation of Jesus, which Mary and St. Joseph carried out perfectly. By entering into the depths of the mystery of the Heart of Jesus, Mary and Joseph received the knowledge and strength necessary to take up and complete their mission. ${ }^{72} \mathrm{Bl}$. Bolesława wrote that gazing on Jesus made Mary and Joseph capable of imitating Him perfectly to the point that they became faithful reflections of $\mathrm{Him} .^{73}$

\section{Conclusion}

Growing in holiness is the essence of the spiritual life. In her teaching, Bl. Bolesława Lament shows the life of the Holy Family as a unique and persuasive model for holiness from which believers can draw the insight that they need. Bl. Bolesława thought that the uniqueness of their example lies in the fact that the Holy Family lived on earth. In addition, because Mary and Joseph knew Jesus in the most intimate way, their example is the starting point for the faithful to grow in a deeper knowledge of and relationship with Jesus.

A study of Bl. Bolesława's writings reveals that, by following the example of the Holy Family's life, a person develops spiritually based on an incarnational concept of holiness, the essence of which is focusing on the mystery of the Incarnation and entering radically into a union with the person of the Son, whom the God the Father sent for the salvation of man. By focusing on the Divine Person of the Incarnate Word, an individual is ushered into the very heart of God's concerns, revealing the eternal plan of God's glory, the essence of which is the revelation of saving love through the Incarnation and Redemption.

According to Bl. Bolesława, the Holy Family example can also help form and increase an apostolic spirit in believers simply by doing that which Jesus, Mary and Joseph did in Nazareth: they grounded their external activities on an interior apostolate that resulted from their personal union with God. In other words, they prayed and offered sacrifice for particular apostolic intentions and thus made the apostolate credible.

\footnotetext{
71 Cf. DBL3, 10-12, 26-27, 30, 41, 49.

72 Cf. DBL2, 219.

73 Cf. DBL3, 52.
} 
Theology of Spirituality

\section{Bibliography:}

1. Balter, L. "Problem udziału św. Józefa w kapłańskiej godności Chrystusa." Ateneum Kapłańskie 96(1981): 280-290.

2. Balter, L. “Królewskość św. Józefa.” Ateneum Kapłańskie 1(1984): 113-127.

3. Balter, L. "Św. Józef jako Prorok." Ateneum Kapłańskie 3(1985): 460-472.

4. Balthazar, H. U. Teologia misterium paschalnego. Translated by E. Piotrowski. Kraków 2001.

5. Bartnik, C. “Odkupienie, usprawiedliwienie i zbawienie.” In: Teologiczne rozumienie zbawienia. Edited by C. Bartnik. Lublin 1979, 9-44.

6. Bernard, C.A. Wprowadzenie do teologii duchowości. Translated by J. Machniak. Kraków 1996.

7. Bochenek, J. Zarys ascetyki. Warszawa 1972.

8. Doze, A. Józef, cień Ojca. Refleksje z duchowości nazaretańskiej. Translated by. L. Balter. Kalisz 2006.

9. Filas, F. L. Święta Rodzina wzorem dla rodzin. Translated by A. Zapał. Sandomierz 2007.

10. Galot, J. "Święty Józef." In: Józef z Nazaretu. Edited by O. Stokłosa. Volume 1. Kraków 1979, 183-310.

11. Garrigou-Lagrange, R. The Three Ages of the Interior Life. Volume 1. Translated by S. Teresa Franciszkanka, Służebnica Krzyża. Poznań 1960.

12. Gogola, J. W. Teologia komunii z Bogiem. Kraków 2003.

13. Greshake, G. "Duchowość Nazaretu". Translated by L. Balter, Communio 1(2005): 98-115.

14. Hryniewicz, W. Chrystus nasza Pascha. Zarys chrześcijańskiej teologii paschalnej. Volume 1. Lublin 1982.

15. Korbut, E. The spirituality of the Missionary Sisters of the Holy Family. Warszawa 2018.

16. Lament, B. Directory of the Congregation of the Missionary Sisters of the Holy Family. Volume 1. Białystok 1944. A-3b-1. Archive of the Congregation of the Missionary Sisters of the Holy Family. Komorów.

17. Lament, B. Directory of the Congregation of the Missionary Sisters of the Holy Family. Volume 2. Białystok 1944. A-3b-2. Archive of the Congregation of the Missionary Sisters of the Holy Family. Komorów.

18. Lament, B. Directory of the Congregation of the Missionary Sisters of the Holy Family. Volume 3. Białystok 1944. A-3b-3. Archive of the Congregation of the Missionary Sisters of the Holy Family. Komorów.

19. Lubac, H. Paradoksy. Nowe paradoksy. Translated by M. RostworskiKsiążek. Kraków 1995.

20. Marchetti, A. Zarys teologii życia duchowego. Volume 1. Translated by E. J. Bielecki. Kraków 1996.

21. Nowak, S. "Mistyka inkarnacyjna Wcielonego Słowa." In: Mistyka droga zjednoczenia z Bogiem. Edited by S. Urbański, M. Szymula. Warszawa 1999, 34-43.

22. Nowak, S. "Wcielenie Syna Bożego jako podstawa duchowości chrześcijańskiej." In: Gdy nastała petnia czasu. Edited by A. J. Nowak. Lublin 2001, 141-152. 
23. Ogórek, P. "Mistyka. Zagrożenie czy rozwój życia duchowego?” In: Mistyka droga zjednoczenia z Bogiem. Edited by S. Urbański, M. Szymula. Warszawa 1999, 11-33.

24. Paszkowska, T. "Wierny prawu i Duchowi - Święty Józef wzorem dla konsekrowanych.” In: Duchowość św. Józefa. Edited by M. Chmielewski. Lublin 2003, 113-129.

25. Paweł VI. "Przemówienie Ojca Świętego z okazji Nawiedzenia Bazyliki Zwiastowania w Nazarecie, 05 I 1964." In: Liturgia Godzin. Volume 1, 378-380.

26. Paweł VI. "Rodzina szkołą świętości. Przemówienie wygłoszone 4 maja 1970 r." Ateneum Kapłańskie 84(1975): 3-13.

27. Pius XII. "Modlitwa do św. Józefa Robotnika.” In: F. L. Filas, Święty Józef człowiek Jezusowi najbliższy. Translated by F. Dylewski, J. Ożóg, D. Siuta. Kraków 1979.

28. Ratzinger, J. The God of Jesus Christ. San Francisco 2008. E-book.

29. Ratzinger, J. Droga Paschalna. Translated by W. Szymona. Kraków 2001.

30. Rybicki, R. "Wychowawca Jezusa Chrystusa." In: Józef z Nazaretu. Edited by O. Stokłosa. Volume 2. Kraków 1979 , 291-335.

31. Schreder, F. “Św. Józef a zjednoczenie hipostatyczne.” In: L. Strada. Patron doskonaty. Kraków 1976, 26-33.

32. Seremak, W. "Św. Józef - szczególny nauczyciel uczestnictwa w mesjańskiej misji Chrystusa." In: Duchowość św. Józefa z Nazaretu. Edited by M. Chmielewski. Lublin 2003, 59-72.

33. Słomkowski, A. Teologia życia duchowego, Ząbki 2000.

34. Urbański, S. "Początek duchowości inkarnacyjnej - 'Gdy nastała pełnia czasu' (Ga 4:4)." In: Gdy nastata petnia czasu. Edited by A. J. Nowak. Lublin 2001, 195-212.

35. Urbański, S. Teologia życia mistycznego. Warszawa 1999.

36. Wejman, H. "Józef z Nazaretu wzorem proegzystencji kapłańskiej." In: Duchowość św. Józefa z Nazaretu. Edited by M. Chmielewski. Lublin 2003, 85-89. 